The Quarterly Journal of Austrian Economics

Volume 23 | NO.3-4 | 427-461 | Fall/Winter 2020 WWW.QJAE.ORG

\title{
Why (A Theory of) Opportunity Matters: Refining the Austrian View of ENTREPRENEURIAL Discovery
}

\author{
Gregory M. Dempster*
}

АвsтRACT: The concept of entrepreneurial opportunity has undergone a period of useful critique and refinement since Venkataraman (1997) and Shane and Venkataraman (2000) employed the term as one of the defining features of entrepreneurship studies. This paper presents a novel Austrian reinterpretation of this concept as an intersubjective phenomenon that emerges from the dual entrepreneurial process of discovery and judgment. Just as markets can be described as price discovery procedures for existing goods, services, and resources, entrepreneurship can be usefully described as a price discovery procedure for future goods, services, and resources. This view retains the essential elements of Kirzner's (1973) approach while also refining the opportunity discovery concept within an evolutionary realist framework for understanding entrepreneurial motivation and action.

\section{INTRODUCTION}

Since Israel M. Kirzner's $(1973,1979)$ groundbreaking work on Sentrepreneurial discovery over forty years ago, the concept of opportunity has been central to the academic literature on venture creation and innovation. Sankaran Venkataraman (1997) and Scott Shane and Venkataraman (2000) made opportunity a primary operational construct in their definition of the field of entrepreneurship

\footnotetext{
* Gregory M. Dempster (gdempster@hsc.edu) is Elliott Professor of Economics and Business at Hampden-Sydney College. 
studies. Though some views, such as those of Frank H. Knight (1921), Joseph A. Schumpeter (1934), and Buchanan and Vanberg (1991) deemphasize the concept in favor of other factors such as uncertainty, innovation, and creativity, the opportunity discovery view has remained a primary construct, often integrated with these other concepts as separate but interrelated aspects of venture creation. Indeed, there is general agreement in the field of entrepreneurship studies that scholars need to "explain the role of opportunities in the entrepreneurial process" and to "clarify the central role that opportunities play in a framework for entrepreneurship" (Eckhardt and Shane 2003, 333).

Recent scholarship, however, has displayed a great deal of ambiguity toward the use of the concept of opportunity, and some have questioned the coherence and usefulness of the term altogether. Distinctions between "Kirznerian" and "Schumpeterian" opportunity are made to distinguish equilibrating from dis-equilibrating entrepreneurial innovations (Shane 2003); "discovery" and "creation" have been proposed as alternate views of how opportunities come into existence (Alvarez and Barney 2007); and both epistemological and methodological objections to the concept itself have been suggested (Klein 2008; Foss and Klein 2012; McCaffrey 2014). The fact that many of these objections come from scholars working in the Austrian scholarly tradition of Kirzner suggests that they represent serious challenges to the viability of the opportunity discovery construct as a research tool in understanding the nature, causes, and consequences of entrepreneurial activity.

This paper seeks to better define the role of opportunity in entrepreneurial discovery. It focuses on entrepreneurship as a collaborative process of intersubjective knowledge generation and integration, and reconceptualizes the idea of entrepreneurial opportunity as neither a purely "preexisting" entity nor a creation of the entrepreneur, but the emergent result of the collaborative process of discovery and judgment. Instead of things in the mind of an entrepreneur, to be either recognized or created as independent constructs, opportunities in this view are defined as decision alternatives that emerge from a set of collaborative procedures for uncovering and integrating localized knowledge, widely dispersed among potential stakeholders, into coherent mean-ends frameworks from which interdependent paths of value creation may 
be identified and potentially exploited for mutual benefit among stakeholders. ${ }^{1}$ In other words, opportunities are endogenous to the process of intersubjective experimentation, selection, and retention that characterizes the market process in general.

This paper places opportunity back in the limelight as a central concept for understanding the causes and effects of entrepreneurship. We argue that this is important for at least three reasons. First, there is the issue of how context affects both motivation and decision analysis behind entrepreneurial actions. Koellinger (2008) argues that examining entrepreneurial behavior involves at least two fundamental questions: (1) What motivates entrepreneurs to choose among alternatives, and (2) where do these decision alternatives come from? Profit motives under uncertainty (i.e., judgment) can, at best, offer only a general answer to the first of these questions, because in complex settings involving nonalgorithmic uncertainty, the very possibilities for ex ante profit cannot be "prestated" (Koppl, Kauffman, Felin, and Longo 2015); characteristics of latent demand and supply are not operational apart from the process by which they are discovered or enacted, and computability limits the effectiveness of policies that presume otherwise (Koppl 2008). In other words, before an entrepreneur can exercise judgment, he or she must hold beliefs in the present about the prospects of profiting from judgment in the future, and both the generation and validation of those prospects in the present is a matter, we argue, of entrepreneurial discovery. Ludwig von Mises (1949 [1996]), who served as one of the primary inspirations for Kirzner's view, suggested that this role of the entrepreneur as both organizer and evaluator is the "driving force" behind the market process; entrepreneurs both "speculate" on uncertain futures and "promote" specific ways of exploiting prospects for advantage from those speculations (250).

Second, there is the issue of differentials among entrepreneurial strategies (see Hitt, Ireland, and Hoskisson 2013). Entrepreneurial strategies are methods by which decision alternatives are evaluated, selected, and pursued. There is a crucial distinction between these

\footnotetext{
${ }^{1}$ This conceptualization of entrepreneurial opportunity echoes that of Shepherd $(2015,491)$, who calls for "thinking of a potential opportunity in terms of a process of social interaction (between a community and the entrepreneur) rather than solely as an outcome of thinking (in the mind of the entrepreneur)."
} 
strategies and the conditions that motivate or enable their use, because the strategies' attributes are contingent on the uncertain unfolding of the market discovery process over time. Not all strategies are equally effective in all contexts; external conditions have much to say about what strategies are effective and under what circumstances. Beliefs about the effectiveness of strategies can be correct or incorrect, and the context of entrepreneurial action, or the opportunity conditions under which it operates, is what ultimately affirms (or not) the correctness of such beliefs. In other words, the existence of opportunity validates not only entrepreneurial beliefs about consumer preferences (ends), but also their beliefs about the best ways to meet those preferences (means).

Finally, there is the issue of differential welfare impacts of entrepreneurial action. Research since Baumol (1990) has confirmed that the entrepreneurial process will produce variability in social welfare outcomes based on the extent to which policies and institutions incentivize value-creating (productive) versus value-dissipating (unproductive) forms of entrepreneurship. More generally, the results of the entrepreneurial process are not confined to the results experienced by individual entrepreneurs; there is a social dimension to entrepreneurial outcomes determined by the character of the institutional capital structure within which they are generated. This social dimension is defined, in part, by the "nexus" (Shane 2003) between the motivations, beliefs, and skills of individual entrepreneurs and the contexts that incentivize and constrain the expression of those motivations, beliefs, and skills. In other words, negative social outcomes do not always come from incorrect beliefs or faulty strategies on the part of entrepreneurs, but often from the limited array of decision alternatives produced by poor institutional contexts.

Simply put, without a meaningful opportunity discovery construct, it is difficult to properly understand the impacts of context, contingency, and institutional capital on entrepreneurial outcomes. This paper represents an attempt to further develop such a meaningful concept, drawing on the work of Kirzner but also on the rich literature that has developed in response to its ambiguous construction and role. The remainder of the paper is organized as follows. First, the role of opportunity in the study of entrepreneurship is surveyed, beginning with Kirzner's seminal 
view and proceeding to recent developments. Both Kirzner's approach and the more recent extensions and modifications of the opportunity construct are critiqued, including those that suggest an outright abandonment of the term. Next, a theory of opportunity development is provided that addresses the major shortcomings of existing versions while retaining their important contextual role, noting similarities to other approaches. Finally, some implications are outlined of this reconceptualization of entrepreneurship as an emergent, collaborative procedure of opportunity discovery and judgment for both strategy research and policy.

\section{THE ROLE OF OPPORTUNITY IN ENTREPRENEURSHIP STUDIES}

Although the systematic study of the entrepreneur goes at least as far back as Richard Cantillon (1755), Jean-Baptiste Say ([1821] 1880), and John Stuart Mill ([1848] 1871), it was the work of Knight (1921), Schumpeter (1934), and, especially, Kirzner (1973) that did the most to incorporate the theory of the entrepreneur into economic and social analysis. Likewise, although the term opportunity has a long history in both academic and popular works on entrepreneurship, the primary theoretical role it plays in entrepreneurship studies derives from the work of the Austrian school, again most directly from Kirzner (1973). One of the best-known expositions of this view is presented in Kirzner $(1979,62)$, where he outlines the essential aspects of what he calls "entrepreneurial discovery," which he describes as the "driving force behind [the] systematic process" of market equilibration.

Kirzner's entrepreneurial discovery view developed primarily out of the insights of Austrian scholars Mises and F. A. Hayek, who were in turn heavily influenced by the ideas of earlier scholars in the Austrian tradition. From Mises ([1949] 1996) comes the concept of entrepreneurship as a process of action under uncertainty, while Hayek $(1945,1948)$ contributes the concept of knowledge acquisition as a fundamental aspect of market interactions (Kirzner 1997, 67). As Kirzner explains, Hayek conceived of markets as processes whereby "market participants acquire better mutual information concerning the plans being made by fellow market participants," while Mises contributed the recognition that "this process is driven 
by the daring, imaginative, speculative actions of entrepreneurs who see opportunities for pure profit in the conditions of disequilibrium" (Kirzner 1997, 68).

There are two important aspects of the preceding views that come to bear on an examination of the opportunity construct. First, from Hayek, opportunities arise as the result of acquiring "better" information about what market participants intend than was previously possessed, a process that Hayek later described as "discovery" (see, e.g., Hayek 1978). Second, from Mises, it is the entrepreneur that recognizes opportunities and engages in actions designed to exploit them. Kirzner (1997) refers to these aspects as the discovery role and the entrepreneurial role, respectively. ${ }^{2}$ Thus, discovery in the Austrian view does not refer to the recognition of opportunities per se, but to the general role of markets as a knowledge acquisition process, from which entrepreneurs learn what opportunities might exist and how to act in order to profit from them. To quote from Hayek $(1948,97)$, markets and competition exist "to teach us who will serve us well: which grocer or travel agency, which department store or hotel, which doctor or solicitor, we can expect to provide the most satisfactory solution for whatever particular personal problem we may have to face." ${ }^{3}$

The Kirznerian entrepreneur is one who looks for "opportunities for pure entrepreneurial profit created by temporary absence of full adjustment between input and output markets" (1973, 69), whether that absence of adjustment is in the present or the future. Full adjustment of input and output markets requires the absence of surpluses and shortages, but also the lack of profit above the opportunity cost of all resources employed in the process. So, for a forward-looking entrepreneur, the ability to correctly foresee a profit situation requires that he, in some way, be able to discover something that is not reflected in the current pricing of resources and/or consumer goods and services. The entrepreneurial roles of recognition and risk taking require the discovery role of knowledge acquisition. Hayek $(1945,1948)$ adds the proposition that this

\footnotetext{
${ }^{2}$ Kirzner (1997) also adds a third aspect, the role of rivalry, as a necessary component of equilibrating market processes. Since this paper does not focus on the equilibrating role of the entrepreneur, we do not emphasize this admittedly important concept.

${ }^{3}$ The author thanks an anonymous reviewer for highlighting this passage.
} 
knowledge is often of the localized, tacit, and intersubjective type that cannot be uncovered without actions (experiments) that submit various ideas to market tests. The picture of entrepreneurship that emerges is very similar to the creative trial-and-error processes that characterize "constructivist" conceptions of venture development, like those of Buchanan and Vanberg (1991) and Sarasvathy (2001). It also bears resemblance to the role of the financial market speculator in Mises ([1949] 1996). ${ }^{4}$

Unfortunately, Kirzner $(1973,1997)$ illustrates this process by employing a framework that assumes an actual, existing supply and demand for consumer goods and services, thus reducing the entrepreneurial function to one of discovering current market inefficiencies, essentially as an arbitrageur. An important aspect of this characterization, as pointed out by Peter G. Klein (2008), is the lack of investment and, thus, risk taking on the part of the entrepreneur. By contrast, Knight (1921) suggests that only when characteristics of future supply and demand are uncertain will an entrepreneurial investment in current resources be necessary, so that the entrepreneur acts as innovator, speculator, and resource allocator in markets for future goods and services, not merely an arbitrageur of divergent market expectations.

Though Klein acknowledges Kirzner's purpose in using the arbitrageur as an illustration, stressing the equilibrating aspect of entrepreneurship in the market process, and that Kirzner himself acknowledged the speculative role of entrepreneurship in other works (see, e.g," Kirzner, 1985, 56), the focus on arbitrage is nonetheless problematic. ${ }^{5}$ Chief among the issues is the idea that entrepreneurs are defined by the characteristic of "alertness" to opportunities, that is, that their primary function is to look for situations where yet unrecognized market inefficiencies already exist. Not only does such a function ignore the important role of uncertainty bearing that creating new goods and services entails, but it is also difficult to operationalize apart from the very actions (investments) that create those goods and services. Essentially, we can only see the ex post

\footnotetext{
${ }^{4}$ This similarity is examined further in the final section of the paper.

${ }^{5}$ An anonymous reviewer points out, correctly, Kirzner's later employment of a multiperiod view emphasizing the psychological component of investment under uncertainty.
} 
results of alertness, and that only when risky investments in assets turn out to have been correct. ${ }^{6}$ By contrast, it is problematic to ascribe unsuccessful investments to "lack of alertness" to an opportunity, as there is no direct evidence that an opportunity existed in the first place; nor can one merely substitute the idea of alertness to a "nonopportunity" to explain unsuccessful investments, because the very idea of alertness implies that something exists to be aware of.

Nonetheless, there is a considerable literature in entrepreneurship that derives its emphasis from this framework. Drawing from Kirzner, Shane and Venkataraman (2000, 200) identify opportunity as a key construct in the definition of what entrepreneurs do and what those who examine entrepreneurship study. They define entrepreneurial opportunities as "situations in which new goods, services, raw materials, and organizing methods can be introduced and sold at greater than their costs of production." Importantly, this definition is noncommittal on the questions of both the nature and sources of entrepreneurial opportunities. The opportunity discovery approach has been employed to fruitfully explore knowledge transfer (Shane 2000), the nature of entrepreneurial searching (Hsieh, Nickerson, and Zenger 2007), venture development in transitional markets (Mainela and Puhakka 2009), the role of transactions costs and property rights (Foss and Foss 2008), the use of intellectual capital (Puhakka 2010), and entrepreneurial networks (Shu, Ren, and Zheng 2018), among numerous other applications.

Management scholars have spent considerable effort trying to better formalize the role of opportunity in the framework of entrepreneurship studies. For example, Sarasvathy, Dew, Velamuri, and Venkataraman (2003) distinguish between three views of entrepreneurial opportunity they identify as allocative, discovery, and creative views. An allocative view of opportunity implies a current misallocation of existing resources; thus, the emphasis is on recognition of discrepancies in current supply and demand, much as illustrated in Kirzner (1997). A discovery view implies that there is one important aspect of a potential market that is undeveloped-i.e., a (latent) demand without a supply or a (latent) supply without a demand. The emphasis in this view of entrepreneurial

\footnotetext{
${ }^{6}$ McCaffrey (2014) also questions the suitability of uncertain profit opportunities as a motivating factor for the characteristic of alertness.
} 
opportunity is on "discovering" where latent supply or demand exist, such as a service without a provider (latent demand) or a resource without a use (latent supply), and completing the market by implementing the missing piece. Finally, a creation view implies that there is neither a supply nor a demand for the good or service in question; in this case, the entrepreneur creates the opportunity by providing both a new good or service and a new set of means by which the good or service is created.

Sharon A. Alvarez, Jay B. Barney, and Susan L. Young (2010) employ a similar approach in their article on opportunity formation. They also use a threefold categorization scheme, focusing on three philosophical approaches to opportunity: realist, social constructionist, and evolutionary realist. Despite the different nomenclature, their views essentially correspond to those of Sarasvathy et al. (2003), with their realist view corresponding to the recognition view, the constructionist to the creation view, and the evolutionary realist to the discovery view of the latter. Confusingly, they refer to methods of "discovery" as applicable to the realist framework, although their description of realism corresponds closely to that of the allocative view in Sarasvathy, et al., (2003); likewise, they ascribe methods of "creation" to the evolutionary realist framework, although their description of this framework corresponds closely to that of discovery in the latter.

A rich literature has developed around constructivist views linked to the "creation" approach since Alvarez and Barney (2007) proposed the basic dichotomy between creation and discovery, including Alvarez and Barney (2010, 2013), Wood and McKinley (2010), Alvarez, Barney, and Anderson (2013), and Alvarez, Young, and Woolley (2015). ${ }^{7}$ The emphasis in each of these extensions is on the idea of "enactment," rather than discovery, of opportunities; as explained by Wood and McKinley (2018), the "causal influence of the entrepreneur on the opportunity is more strongly highlighted" than in the discovery view (8). The opportunity creation literature has expanded considerably to include the examination of niche

\footnotetext{
${ }^{7}$ Though Alvarez and Barney (2007) are generally credited with the discovery-creation dichotomy, earlier research had identified important aspects of the distinction. See, e.g., Buchanan and Vanberg (1991), Chandler, DeTienne, and Lyon (2003), and Baker and Nelson (2005).
} 
construction (Luksha 2008), information technology startups (Ojala 2015), entrepreneurial affect (Goss and Smith 2018), the conditions of uncertainty underlying entrepreneurial actions (Mitchell et al. 2012), and social entrepreneurship (Gonzalez, Husted, and Aigner, 2017). Several studies have also attempted to bridge and / or reconcile the opportunity discovery and opportunity creation approaches (see, e.g., Zahra 2008; Edelman and Yli-Renko 2010; Martin and Wilson, 2016; and Chetty, Karami, and Martin, 2018).

Although maintaining the importance of opportunity, however, the essence of the creation view still locates it solely in the mind of the entrepreneur. In doing so, this view fails to address the important problems of where entrepreneurial beliefs come from and why entrepreneurs perceive the decision alternatives that they do, particularly those alternatives that ultimately prove successful. The idea that successful entrepreneurship requires some knowledge of future conditions outside the mind of the entrepreneur seems to also require that there be entrepreneurial methods of "discovering" what those conditions are. Thus, at the heart of the dichotomy between creation and discovery are the questions of what ultimately makes entrepreneurial profit seeking successful, and whether it lies entirely within the entrepreneur's imagination or at least in part in the recognition of external realities that give it credence.

Other extensions of the opportunity literature have attempted to better integrate it with more traditional views in psychology and evolutionary economics, such as the cognition-based approach of "opportunity recognition" (see, e.g., Baron 2004, 2006; Baron and Ensley 2006; and Ozgen and Baron 2007) and the idea of opportunities as "propensities" (Ramoglou and Tsang, 2016, 2017). Baron (2004, A1) proposes opportunity recognition as a form of pattern recognition, the "process through which individuals perceive emergent patterns among seemingly unrelated stimuli or events." As such, opportunity recognition is a form of discovery informed by theories of human cognition and perception. Similarly, Ramoglou and Tsang (2016, 2017) propose that opportunities are real propensities for a future, emergent state of the world and that entrepreneurs sometimes recognize these propensities and act to bring them to fruition, much as one who recognizes the future plant within a seed must act to bring the plant into being. This evolutionary-realist view of opportunities as propensities is further examined below. 
One way to examine the validity and completeness of alternate views of entrepreneurship is to ask how entrepreneurial behavior would be different under the different approaches. For example, consider the distinctions between discovery and creation as illustrated by Sarasvathy et al. (2003) and Alvarez, Barney, and Young (2010). Under the realist approach of Alvarez, Barney, and Young, analogous to Sarasvathy, Dew, Velamuri, and Venkataraman's allocative view, the entrepreneur acts as the Kirznerian arbitrageur; entrepreneurs seek pure profit by addressing an existing market disequilibrium. Although such a view is plausible in many cases, it does not address the important Knightian roles of risk taking and investment under uncertainty, which characterize ventures to provide future goods and services. By contrast, under Alvarez, Barney, and Young's constructionist approach, analogous to Sarasvathy et al.'s creation view, individuals develop both the opportunity and the market for it through their actions. They "do not recognize opportunities first and then act; rather, they act, wait for a response-usually from the market-and then they readjust and act again" (Sarasvathy et al. 2003, 30, emphasis mine). The implication is that it is entirely the actions of entrepreneurs that produce an opportunity-no latent market characteristics (demand or opportunity cost) exist independently that can be employed as motivation for actions or justification for beliefs.

However, the idea that entrepreneurs act without either motivation from or beliefs about latent external characteristics does not hold up to logical scrutiny, because it dodges the question of why entrepreneurs act at all. Although it is true that a yet undiscovered objective opportunity cannot serve as its own motivation for discovery, neither can purely subjective perceptions of an opportunity do so. The real question here is one of incentives-why do entrepreneurs believe that there are ex ante profit opportunities available? Do they not expect that, in some objective sense, their actions will result in an expected benefit above the opportunity cost of the action? What is the basis for a belief of this kind, and from where does the feedback that potentially affirms or alters the belief come? Hayek suggests that it comes in the form of information (i.e., revealed preferences) about the subjective perceptions of consumers and resource owners regarding the expected benefits and opportunity costs of future goods and services. In other words, 
it reflects underlying realities of (latent) supply and demand as revealed by consumers and resource owners. If this were not true, it would be difficult to understand how one could explain market feedback as a test of validity of the entrepreneur's actions-and, by extension, the validity of the opportunity-because the concept of feedback requires some revelation about preferences not previously obtained by the learner, who is the entrepreneur. ${ }^{8}$

Taking a different approach, Klein (2008) and Nicolai J. Foss and Klein (2012) introduce the concept of judgment, derived from the work of Knight (1921). Judgment is defined as "decision making when the range of possible future outcomes, let alone the likelihood of individual outcomes, is generally unknown" (Klein 2008, 177). In other words, judgment refers to the choice among alternatives when both the full scope of alternatives and their probabilities are noncomputable. The entrepreneurial function, in this view, is to evaluate decision alternatives for bringing future goods and services into being and, if necessary, make risky investments in assets with the aim of profiting from those evaluations. This approach, although in a younger stage of development, has produced a significant literature of analysis and critique in both management and economics (see, e.g., Sarasvathy and Dew 2013; McCaffrey 2014, 2015; McMullen 2015; Foss and Klein 2015; Godley and Casson 2015; Hallberg 2015; and Foss, Klein, and Bjørnskov 2019).

However, while adequately addressing the evaluation and exploitation of potential opportunities for profit, judgment does not address the motivation for such judgments or the generation of decision alternatives any better than alertness (of objective circumstances) or creation (around purely subjective beliefs) do. The problem centers on an important flaw that is common among constructivist critiques of the opportunity concept: the idea that, since the actual existence of opportunity can never be revealed except where (successful) entrepreneurial action confirms its existence, opportunity itself must be entirely subjective, i.e., it exists only in the mind of the entrepreneur. Klein (2008) states this succinctly when he writes:

\footnotetext{
${ }^{8}$ This emphasis on the role of the entrepreneur in "discovering" the preferences of the consumer is also explicit in Mises ([1949] 1996).
} 
Expectations about the future are inherently subjective and, under conditions of uncertainty rather than risk, constitute judgments that are not themselves modelable....[o]pportunities for entrepreneurial gain [and] are, thus, inherently subjective-they do not exist until profits are realized. (180-81, emphasis mine)

Consistent with this line of reasoning, Foss and Klein (2012) propose the alternative judgment-based approach (JBA) focusing on beliefs, actions, and results. Employing this approach, they suggest that the notion of opportunity can only be understood as an ex post construct and that the ex ante correlate is entrepreneurial beliefs, which are translated into actions stemming

from 1) more or less articulated business plans ultimately based on knowledge and beliefs about current conditions and 2) estimates of future profits and losses that result from realizing the business plans. (Foss, Klein, and Bjørnskov 2019, 1204, emphasis mine)

The problem with this and similar characterizations of the subjective nature of opportunities is that they confuse the existence of latent preferences in the marketplace, preferences that can potentially be discovered by entrepreneurs who are motivated to find ways to profit from their own subjective beliefs about those preferences, and the revelation of those preferences, which occurs when entrepreneurs submit their ideas to the market tests that produce feedback about the correspondence of their beliefs to actual circumstances. Although it is true that entrepreneurial beliefs are purely subjective, the feedback entrepreneurs receive from market tests of their ideas is not; it is more correctly considered intersubjective (Sarasvathy and Venkataraman 2011; Venkataraman et al. 2012; Garud and Giullani 2013), because it contains information about the congruence (or lack thereof) between subjective beliefs on the part of the entrepreneur and subjective preferences expressed by market participants. Nicolai J. Foss, Peter G. Klein, and Christian Bjørnskov (2019) implicitly acknowledge the problem when they refer to plans that are "based on knowledge and beliefs about current conditions," but fail to provide an explanation of how (or why) knowledge of current conditions shapes the motivations for and accuracy of those beliefs without methods of discovery. 
Treating opportunities as purely subjective entities ignores the most important aspect of what Kirzner was trying to convey with his entrepreneurial arbitrageur, namely, the systematic search for and recognition of situations, whether temporally located in the present or in the future, where the characteristics of latent supply and demand (i.e., preferences) do not match objective price conditions. These situations are what we refer to as opportunities, and they are revealed when market tests show entrepreneurial beliefs about underlying preferences to be accurate and/or when they provide additional information necessary to adjust entrepreneurial actions to accurately reflect or influence those preferences. ${ }^{9}$ Discovery is the process that reveals this information to the entrepreneur.

Another approach, mentioned above, that has recently flourished is the idea of opportunities as propensities (Ramoglou and Tsang 2016, 2017). This approach conceives of opportunities as objective constructs of latent demand or supply but outside the mind or consciousness of the entrepreneur, who "actualizes" them through attempts to match their beliefs about the profitability of future goods and services to data provided via market tests. Opportunities, in this view, are not directly observable but "can be evidenced through their effects," as Stratos Ramoglou and Eric W. K. Tsang $(2016,412)$ explain. Their view comes closer to the opportunity discovery view proposed here in allowing for a realist construct for opportunity; in contrast to the constructionist views, they reject opportunity as only existing in the mind of the entrepreneur. However, Ramoglou and Tsang's actualization approach also rejects a purely empiricist view of opportunity, which they refer to as discovery. Nonetheless, one can take this as a starting point for a reexamination of exactly what discovery and opportunity contribute to the emerging conversation on entrepreneurship.

The two lines of research examined above not only propose to represent the "middle ground" between the discovery and creation approaches described earlier, but also place themselves as correctives or reconstructions of the Kirznerian approach based in Mises and Hayek. Thus, further refinements in the Austrian view of entrepreneurship must take account of their critiques and incorporate their

\footnotetext{
${ }^{9}$ Lewin (2015) refers to these intersubjective characteristics of opportunity as shared understandings.
} 
positive developments. We argue here that these critiques, although useful, have nonetheless erred in failing to distinguish between two aspects of subjective judgment that are important to understanding the motivations for and results of entrepreneurial action: the beliefs and aspirations of the entrepreneur and the preferences of the consumers whose wants they intend to fulfill with their business plans. For example, Foss, Klein, and Bjørnskov $(2019,1198)$ state: "We think that what is often meant when scholars (and practitioners) use the opportunity construct is that entrepreneurs hold certain beliefs concerning what they think they can do with their resources....But, it doesn't seem natural to call such beliefs, plans or projects 'opportunities.'” Likewise, Ramoglou and Tsang (2016, 416) reject the "inapt" term discovery as "linguistic malpractice" because it lures us into "inferring that opportunities must exist as actualized entities that can be somehow observed."

The opportunity discovery approach does not deny that both beliefs and preferences are subjective phenomena-in fact, no "Austrian" view could reasonably do so. The question is not whether they are individually subjective, however, but whether the conditions under which they happen to dovetail are subjective. In other words, does the fact that entrepreneurial outcomes are based, in part, on how well entrepreneurs understand or anticipate actual future conditions mean anything for understanding their beliefs, actions, results? Discovery means that when successful entrepreneurs explore "business plans" and "actualize" those plans into profits there has been recognition of something meaningful about the real world. Therefore, can we not meaningfully describe what they have recognized as a phenomenon (an opportunity) that, in part, framed those plans and shaped the actions by which they succeeded?

Foss, Klein, and Bjørnskov's (2019) JBA framework concedes that entrepreneurial business plans are ultimately based on knowledge and beliefs about current conditions, but it is unclear from where that knowledge (and the corresponding beliefs) about conditions comes from. As pointed out by Ramoglou and Tsang, "[d]espite the subjectivity of goals, the conditions of their satisfaction lie in the objective conditions of the world" (2016, 417). Using a commonsense definition of opportunity as a set of circumstances that make something (like a goal) possible, or "a favorable juncture 
of circumstances," ${ }^{10}$ one might argue that correct knowledge about favorable conditions comes from discovery of at least some of those conditions; to argue otherwise would seem to leave "luck" as the only explanation for successful (i.e., profitable) entrepreneurship. Indeed, examinations of the actual processes employed by expert entrepreneurs suggests that they spend a considerable amount of time and effort both uncovering and manipulating the conditions of opportunity via means of effectual reasoning (Sarasvathy 2001).

\section{DISENTANGLING BELIEFS, ACTIONS, AND RESULTS: ENTREPRENEURSHIP AS PRICE DISCOVERY}

The term discovery is as apt a word as any to describe the process by which entrepreneurs seek to verify the existence of opportunities and fits with the commonsense notion of opportunity as something that exists, in part, due to knowledge of external realities. Along these lines, Jeffrey S. McMullen and Dean A. Shepherd (2006) make a useful distinction between two types of opportunities, third-person and first-person. A third-person opportunity refers to a "potential opportunity for someone in the marketplace" (ibid., 137); entrepreneurs identify these potential opportunities by being attentive, or exhibiting what Kirzner (1973, 1997) refers to as alertness. Third-person opportunities are reflections of both the preferences of the entrepreneur and those of potential stakeholders; they are the basis for actions that may create something more concrete, a first-person opportunity. First-person opportunities can only exist in correspondence with actions on the part of entrepreneurs; they do not, in fact, exist independently of those actions. Tests of validity against "objective reality" (Alvarez, Barney, and Young 2010, 30), therefore, amount to tests of whether first-person (actual) opportunities envisioned by entrepreneurs reflect an underlying reality expressed in their beliefs about third-person (potential) opportunities; equivalently, they are tests of whether preferences revealed by entrepreneurial actions correspond to entrepreneurial beliefs about the existence of those preferences.

\footnotetext{
${ }^{10}$ Merriam-Webster, s.v. "opportunity (n.)," accessed June 1, 2020 from https://www. merriam-webster.com/dictionary/opportunity.
} 
Disentangling opportunities into their exogenous, third-person and endogenous, first-person components goes a long way in clarifying the role of opportunity in motivating entrepreneurial action. Third-person opportunities may exist independently of entrepreneurial actions; they can be missed or misperceived; they can be well exploited, imperfectly exploited, or go unexploited; they represent the commonsense notion of opportunity as a set of conditions favorable to action that is value enhancing (i.e., produces benefits in excess of opportunity cost) for some set of stakeholders. They can serve as motivation (incentives) for engaging in actions intended to reveal characteristics of latent supply and demand for goods and services that are not yet in existence. However, first-person opportunities are not revealed independently of entrepreneurial actions; they are contingent upon those actions. They exist only in the sense that actions show them to be valid when entrepreneurs submit their initial and subsequent perceptions of benefit and opportunity cost to market tests. This conforms to the notion of opportunities as conditions of value creation revealed via correct judgments of future preferences.

The third-person/first-person distinction, however, does not go far enough in many ways. It does not address the generation of decision alternatives, nor the tendency (or lack thereof) for those alternatives to match actual preferences. This discovery of intersubjective agreement between entrepreneurial beliefs and consumer preferences, and the subsequent replacement of less correct prices with more correct prices for both resources and goods, is the sine qua non of the Austrian approach to entrepreneurship and is what distinguishes the role of entrepreneurship in the Austrian tradition from its passive role in neoclassical economics and its uncertainty-enhancing role in post-Keynesian approaches (see, e.g., Dempster 1999). The discovery approach of Mises, Hayek, and Kirzner thus conceives of entrepreneurship as an essential error correction procedure within the market process.

Entrepreneurship researchers in management, even some of whom adhere to a constructivist view of entrepreneurship, have recognized the problem with thinking of opportunity in a purely subjective sense. Per Davidsson (2015), though skeptical of the usefulness of the opportunity construct, concedes that opportunity exists in recognizing that subjective perceptions of 
market disequilibrium (an objective phenomenon) motivate entrepreneurial actions and provide an explanation for their success. Matthew S. Wood and William McKinley (2018), in presenting a case for retaining the opportunity construct as an umbrella concept in entrepreneurship research, argue that the construct is necessary to help researchers distinguish means from ends, to account for feedback from market tests (preference revelation), to avoid ambiguity (between beliefs, judgments, and actions), and to link entrepreneurship to practice, where the notion of opportunitiesboth successfully exploited and missed-is part of the generally accepted norms of language in entrepreneurship. This discussion supports these conclusions and provides an additional rationale for retaining the opportunity construct, namely, that it correctly describes the situation of congruence between the judgment of decision alternatives and the characteristics of subjective preferences that determine the correctness of those judgments. In this view, opportunities are neither merely "out there," existing independently of entrepreneurial beliefs and actions, nor are they purely subjective creations in the mind of the entrepreneur. Instead, they refer to conditions under which preference revelation indicates disequilibrium between actual prices of resources and goods and their intersubjective (shared) values.

In this article the concept of discovery is refined as the processing of information into knowledge (Foss, Klein, and Bjørnskov 2019, 1204) that allows entrepreneurs to replace less correct prices with more correct ones based on the revelation of unsatisfied preferences for new goods and services in new markets. In other words, discovery and opportunity coevolve as mutually reinforcing components of the entrepreneurial process. There can be no recognition of opportunity without successful discovery, just as there can be no revelation of opportunity without successful judgment. In this sense, the idea of discovery as the result of alertness to preexisting (objective) opportunities is merely being replaced with a more plausible idea of discovery as a corollary to the emergence of (intersubjective) opportunities. Unlike the former, this view allows not only for the possibility that opportunities are real things, with real properties that correspond to actual states of the world, but also for the possibility that discovery fails to identify an opportunity, either because the characteristics of the opportunity were different from what the 
entrepreneurs imagined (a missed opportunity) or because there was never an opportunity in the first place (a nonopportunity). ${ }^{11}$

The preceding discussion, therefore, highlights four important aspects of opportunity discovery for the study of entrepreneurship: (1) motivations for entrepreneurial actions, (2) generation of decision alternatives, (3) convergence of subjective beliefs and subjective preferences, and (4) welfare impacts of variability in entrepreneurial strategies. We address these aspects by employing a simple model of the entrepreneurial process. The model abstracts from admittedly important elements in the process. Nonetheless, it provides a useful framework for understanding the important differences between subjective and intersubjective phenomena, and the corresponding differences between discovery and judgment that are important for delimiting the role of the opportunity construct. Figure 1 below illustrates the model.

\section{Figure 1. The Entrepreneurial Discovery Process}

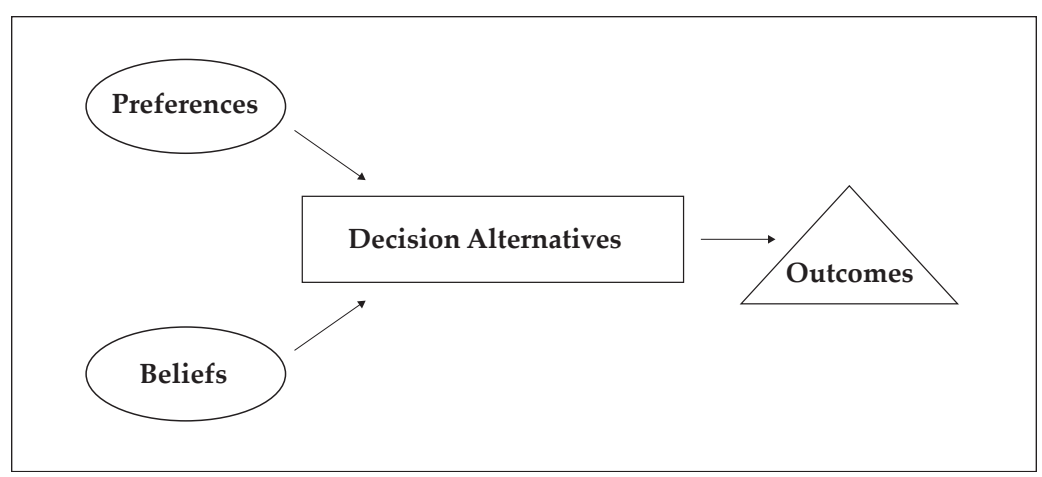

The entrepreneurial process begins with the subjective phenomena that make up the material for value judgments: the subjective preferences of individuals in the marketplace with respect to benefit and cost, and the beliefs of individuals that might profit from an understanding of those preferences, i.e., potential entrepreneurs. These entrepreneurial beliefs consist of evaluations of what others' preferences are, what kinds of ventures and strategies might be

\footnotetext{
${ }^{11}$ On the concept of nonopportunity, see, e.g., Ramoglou and Tsang (2016, 420-21).
} 
profitably employed to satisfy those preferences, and what benefits and costs might be earned and incurred as the result of actions to implement such ventures and strategies. Importantly, these beliefs may vary widely in their accuracy concerning any of these things; potential entrepreneurs begin with only an imperfect understanding of preferences, strategies, and consequences. Nonetheless, if entrepreneurial beliefs suggest a value-creating allocation of future resources that differs from the current allocation that might earn an economic profit, the potential entrepreneur may be motivated to engage in a Hayekian discovery procedure, whereby they gather information to validate, modify, or falsify their own beliefs.

It is here that the conceptualization presented in this article differs from the standard Kirznerian view of opportunity discovery. At this point, the most that can be said of the potential entrepreneur is that they possess beliefs and motivation. However, an effectual (Sarasvathy 2001) process of discovery can reveal possibilities of convergence between entrepreneurial beliefs and the subjective preferences of individuals that represent decision alternatives. Among these decision alternatives may be opportunities for profitable actions. The process itself is collaborative, requiring that the entrepreneur interact with the market environment (and the individuals in it), identify and recruit important stakeholders, and learn from both direct and indirect experience to discover whether and how intersubjective convergence of personal beliefs and the realities of preferences might be achieved. If such an intersubjective convergence takes place-itself an uncertain proposition-an opportunity can be said to exist. Thus, opportunities arise as possibilities for profitable action among decision alternatives. Table 1 below illustrates this result.

Table 1. Outcomes of the Discovery Process

\begin{tabular}{|c|c|c|c|}
\hline \multirow{4}{*}{ Beliefs } & \multicolumn{3}{|c|}{ Price-Preference Alignment } \\
\hline & & High & Low \\
\hline & Correct & Nonopportunity & Valid opportunity \\
\hline & Incorrect & Mistaken judgment & Missed opportunity \\
\hline
\end{tabular}


As indicated in the table, there are basically four possible outcomes of the entrepreneurial discovery process. One possibility is that the entrepreneur discovers that consumer preferences with respect to the area of investigation are in line with the opportunity costs of resources. In other words, there is no "third-person" opportunity to explore. This is what would most correctly be termed a nonopportunity; it refers to the situation where gains from entrepreneurial action are not expected under correct assumptions about the reality of the external environment, including both actual and latent preferences. A second possibility is that the entrepreneur believes an opportunity exists when it, in fact, does not. This would be an example of mistaken judgment on the part of the entrepreneur. A third possibility is that an opportunity for realignment of preferences with prices is possible but that discovery fails to reveal this to the entrepreneur. This is, quite simply, a missed opportunity. Finally, there is the case where entrepreneurial discovery correctly notices and diagnoses a possibility for realignment; this is where intersubjective convergence of entrepreneurial beliefs and consumer preferences results in a valid opportunity for action. Although this does not guarantee a successful venture-entrepreneurial judgment may still fail to implement the appropriate strategies for successful exploitation-it is nonetheless a precondition for successful judgment. No amount of expert judgment can overcome a lack of intersubjective convergence between consumer preferences and entrepreneurial beliefs. ${ }^{12}$

In this view, there is no reason to assume that either (a) opportunity (convergence) always results from the discovery process or (b) entrepreneurs engaging in discovery always recognize and/or exploit the opportunities that emerge. Opportunities are uncertain; they can fail to emerge, they can emerge and be missed, or they can emerge, be recognized, and still fail to be taken advantage of with the correct entrepreneurial judgments and investments. Thus, Foss and Klein's (2012) judgment-based approach is not entirely at odds with the view expressed here. Rather, it is more correct to say that the

\footnotetext{
${ }^{12}$ Put differently, if judgment is the ability to "accurately assess, estimate, or infer others' preferences" (McMullen 2015, 654), then discovery of intersubjective convergence (i.e., opportunity) is a necessary prerequisite for a correct judgment that results in a profitable investment; otherwise, correct judgment will result in no investment action at all.
} 
process by which an opportunity is discovered is operationally distinct from the process by which judgments are made. Correct (successful) judgment requires correct (successful) discovery, but discovery itself does not ensure correct judgment. Foss and Klein are correct to emphasize a previously underexplored aspect of the entrepreneurial process but are incorrect in suggesting that discovery is unimportant. The framework presented here incorporates elements of both and may thus be expressed as a discovery-judgment view (DJV). This view of opportunity discovery fits well within the parameters of evolutionary reasoning as well as with notions of pattern recognition emphasized by Baron $(2004,2006)$. Most importantly, it makes a useful distinction between the information-gathering (discovery) and decision-making (judgment) elements of the entrepreneurial process.

\section{APPLICATIONS OF THE DISCOV- ERY-JUDGMENT VIEW TO ENTREPRENEURIAL STRATEGY AND POLICY}

Our view suggests that the motivation for entrepreneurial actions is the possibility of intersubjective convergence between beliefs and preferences in a future goods space. Thus, it indicates a distinction between the conditions of opportunity and the strategies for recognizing and exploiting them. This is at the heart of Mises's ([1949] 1996, 214) distinction between the capitalist-entrepreneur-the uncertainty-bearing aspect of entrepreneurship emphasized in Knight (1921) and in the JBA framework-and the entrepreneur promoter, who speculates on behalf of the capitalists. This entrepreneur not only speculates about future conditions that may bring about profits, as a pure capitalist might, but also formulates specific plans (strategies) to adjust production to the expected future conditions. Entrepreneurs are more than just risk takers; they are the actors who imagine, explore, and validate decision alternatives regarding future resource allocations.

Strictly speaking, economics does not suggest that consumers want goods and services, per se; what they desire-and are willing to sacrifice for-are the "features" of goods and services. Features are what make up consumer preferences, not goods and services, because it is the advancement of subjective ends like happiness, health, comfort, prestige, contentment, joy, status, power, etc. that 
individuals are trying to satisfy when they sacrifice resources to obtain goods and services (see, e.g., Gorman 1959, 1980; Lancaster 1966, 1971; and Becker 1965, 1981, 2007). Therefore, the "discovery" aspects of entrepreneurship does not mean discovery of individuals' demand for iPhones or ride sharing services, but the discovery of preferences that suggest something like an iPhone or a ride sharing service might be demanded at a price above opportunity cost. In other words, discovery does not require that a fully formed idea of a product or service be in the mind of either the entrepreneur or the consumer, only that the entrepreneur be able to gather and process information about consumer preferences and relate it to their own ideas about the use of resources and their opportunity costs. It does not require a demand for any particular thing. ${ }^{13}$ Before introducing products like iPhones or ride sharing services into the marketplace, entrepreneurs examine evidence of consumer preference for features of these goods (like the convenience of ride sharing, internet connectivity, or any of the other characteristics that make them desirable), what consumers might be willing to sacrifice for them, and the opportunity costs of including them in the bundle of features that define the good or service. This is what we mean by discovery.

A useful analogy is that of entrepreneurial strategy as an options-producing (or options-writing) process. In finance theory, option writers obligate themselves to future courses of action without the certainty of knowing that those courses of action will turn out to be profitable; they provide options for others to submit as tests of those expectations. The writer obligates himself or herself to a course of action that depends on the subsequent decision of the purchaser of the option to exercise it or not. If conditions turn out to be favorable for exercise, the option writer stands as the counterparty (buyer for the option to sell, seller for the option to buy) to the option holder; if not, the option expires unexercised along with the obligation of the writer. Option writers seek to benefit from future market conditions by receiving more in profit from the sale of options than they incur in costs of obligations. ${ }^{14}$ One can define

\footnotetext{
${ }^{13}$ In fact, this must be precisely what Ramoglou and Tsang mean by "propensities," because they are the "seeds" from which a fully formed demand must eventually emerge.

${ }^{14}$ One of the most well-known models of options pricing, the Black-Scholes option pricing model, estimates this value (premium) as a function of five simple features:
} 
entrepreneurial strategy as the options-writing process applied to the creation of new paths of future resource allocation, i.e., the writing of real, as opposed to financial, options. It is, to paraphrase Jean-Baptiste Say, the application of knowledge to a potentially useful purpose (Hebert and Link 1982, 31), and the process that produces this knowledge and its application is the work of entrepreneurial discovery, both within and without existing firms.

The options-writing perspective has implications for our understanding of entrepreneurial strategy. First, the entrepreneurial function can be thought of as encompassing two very different roles, often fulfilled by different actors. The writers of real options comprise the actors who engage in a systematic process designed to explore third-person potential opportunities and examine the first-person characteristics of those opportunities by submitting them to market tests. These are Mises's ([1949] 1996) entrepreneur promoters; they are what we traditionally think of as the Schumpeterian entrepreneur who searches for new means-ends frameworks, or a new "production function" (Schumpeter 1934). The entrepreneur promoter must also be able to "engineer agreement among all interested parties, such as the inventor of the process, the partner, the capitalist, the supplier of parts and services, the distributor, etc." (Hirschman 1958, 17). ${ }^{15}$

Mises ([1949] 1996) also refers, however, to the risk-taking and judgmental aspects of entrepreneurship fulfilled by those who choose from among various options to bring first-person ventures into existence via funding and expertise. These capitalist-entrepreneurs are the ones who are responsible for making the crucial decisions that direct resources toward specific ventures-and, by extension, not toward others. This aspect of the entrepreneurial process refers to the outcome of trial-and-error market tests intended to evaluate third-person opportunities for first-person significance, as well as the associated asset-specific investments necessary to materialize the chosen options. David A. Harper (1996, 34) refers to this part of the process as the "internal architecture

the price of exercise, the spot price of the underlying asset(s), the expected volatility of the underlying asset price(s), time until exercise, and the risk-free rate of return.

${ }^{15}$ This description suggests a strong affinity with the stakeholder approach of Parmar et al. (2010) and others. 
of a business enterprise [that] affects the acceptance and rejection of entrepreneurial hypotheses and enterprising activity." Just as financial options purchasers give actual existence to an options contract by agreeing to include it their portfolios, capitalist-entrepreneurs attempt to actualize opportunities by expending resources (financial, intellectual, and social capital) to bring them to fruition. ${ }^{16}$

Notice that in the analogy of the options process to the entrepreneurial process, the entrepreneur promoter takes the role of the options writer, while the capitalist-entrepreneur takes the role of the option purchaser. Mises ([1949] 1996, 215) realized that these two roles are often entangled because we use one term, entrepreneur, to express both aspects of the entrepreneurial process. Therefore, the tension between Schumpeterian innovation and Kirznerian price discovery is the result of linguistic confusion over what aspect of the entrepreneurial process is being emphasized. This paper has argued that the tension between creation and discovery is, in part, the result of this same confusion. The very term entrepreneur is an umbrella concept that describes several functions of innovation, promotion, and risk taking (Hebert and Link 1982) that evolve within the same process.

Further, it is not necessary that the entrepreneurial roles implied by the options analogy refer to distinct parties. Entrepreneur promoters, unlike financial option writers, typically devise and arrange contracts that allow them to direct resources contingently toward the developing ends and to share in the upside potential of the future resource allocation paths they identify. ${ }^{17}$ Likewise, unlike financial option holders, capitalist-entrepreneurs often take an active role in the development of the market tests that identify potential opportunities. This view of the dual nature of entrepreneurial strategy - the direction of attention and decision alternative generation by entrepreneur promoters, and the direction of resources and risk taking by capitalist-entrepreneurs-allows us to build a conceptual bridge between the subjective, speculative nature of entrepreneurial search and the objective, concrete nature

\footnotetext{
${ }^{16}$ This underscores the importance of a well-functioning financial system directing resources and expertise to the most valuable ventures (Dempster 2015).

${ }^{17}$ An exception would be those who search for opportunities with the intent of selling them to others.
} 
of entrepreneurial action. It is, thus, a description of Sarasvathy and Venkataraman's $(2011,125-27)$ notion of intersubjectivity as the concept that links the identification of market problems with their solutions via a coherent, directed process of knowledge integration and informational synthesis.

The view presented in this article also provides a more stable framework for exploring and understanding the public policy implications of variability in the institutional contexts of entrepreneurial action. Baumol (1990) and subsequent work (see, e.g., Acemoglu, Johnson, and Robinson 2001; Boettke and Coyne 2009; Sobel, Clark, and Lee 2007; Sobel 2008; and Dempster and Isaacs 2017) emphasize the importance of institutions for determining the social welfare consequences of entrepreneurial action. In short, institutions incentivize differences in entrepreneurial strategies that may be either welfare enhancing or welfare reducing from a societal standpoint. Entrepreneurs choose strategies for exploiting perceived opportunities based on their estimates of private benefit and cost, which may or may not reflect social benefit-cost ratios. Thus, it is possible that entrepreneurial discovery could result in decision alternatives that anticipate private net benefits while also resulting in net social welfare losses. Simple examples include perceived opportunities exploited via corruption, political reallocation of resources, or the establishment of monopolistic barriers to entry. In maintaining the central position of opportunity in the analysis of entrepreneurial action, the view presented here provides a framework for examining variability in the social welfare impacts of alternative decision strategies that other approaches which have jettisoned the theory of opportunity discovery will tend to obscure.

\section{CONCLUSIONS}

The concept of entrepreneurial opportunity has undergone a period of useful critique and refinement since Venkataraman (1997) and Shane and Venkataraman (2000) first employed the term as one of the defining features of entrepreneurship studies. This article has incorporated much of the research in this area over the past two decades to formulate a novel Austrian reinterpretation of this concept as an intersubjective phenomenon that emerges from the entrepreneurial process of discovery and judgment. This view 
recognizes the inherent problems with the traditional Kirznerian portrayal of discovery as a matter of alertness or attentiveness to preexisting conditions and instead conceives of entrepreneurship as a price discovery procedure for the emergence of future goods, services, and resources within an evolutionary realist framework. In this framework, entrepreneurial motivations and actions are reflections of the expectation of actual, but yet-to-be-revealed, conditions here described as opportunities, and the process by which these expectations are formed and validated is described as discovery. Discovery is, thus, distinct from judgment, as it describes the process that allows judgment to be exercised, i.e., it is an antecedent to judgment. This view retains the importance of the anticipation of intersubjective agreement between entrepreneurial beliefs and consumer preferences as the sine qua non of the Austrian view of entrepreneurship while jettisoning problematic descriptions of opportunity discovery as the result of superior attentiveness to the preexisting conditions of supply and demand.

\section{REFERENCES}

Acemoglu, Daron, Simon Johnson, and James A. Robinson. 2001. "The Colonial Origins of Comparative Development: An Empirical Investigation." American Economic Review 91, no. 5: 1369-1401.

Alvarez, Sharon A., and Jay B. Barney. 2007. "Discovery and Creation: Alternative Theories of Entrepreneurial Action." Strategic Entrepreneurship Journal 1, no. 1-2: 33-48.

—_. 2010. "Entrepreneurship and Epistemology: The Philosophical Underpinnings of the Study of Entrepreneurial Opportunities." Academy of Management Annals 4: 557-83.

—_. 2013. "Epistemology, Opportunities, and Entrepreneurship: Comments on Venkataraman et al. (2012) and Shane (2012)." Academy of Management Review 38: 154-57.

Alvarez, Sharon A., Jay B. Barney, and Philip Anderson. 2013. “Forming and Exploiting Opportunities: The Implications of Discovery and Creation Processes for Entrepreneurial and Organizational Research." Organization Science 24, no. 1: 301-17. 
Alvarez, Sharon A., Jay B. Barney, and Jennifer L. Woolley. 2015. “Opportunities and Institutions: A Co-creation Story of the King Crab Industry. Journal of Business Venturing 30, no. 1: 95-112.

Alvarez, Sharon A., Jay B. Barney, and Susan L. Young. 2010. “Debates in Entrepreneurship: Opportunity Formation and Implications for the Field of Entrepreneurship." Pp. 23-45 in Handbook of Entrepreneurship Research: An Interdisciplinary Survey and Introduction, ed. Zoltan J. Acs and David B. Audretsch, 2d ed. New York: Springer.

Baker, Ted, and Reed E. Nelson. 2005. "Creating Something from Nothing: Resource Construction through Entrepreneurial Bricolage." Administrative Science Quarterly 50: 329-66.

Baron, Robert A. 2004. “Opportunity Recognition: A Cognitive Perspective." Academy of Management Proceedings 2004, no. 1: A1-A6. https://journals. aom.org/doi/10.5465/ambpp.2004.13862818.

—_ 2006. "Opportunity Recognition as Pattern Recognition: How Entrepreneurs 'Connect the Dots' to Identify New Business Opportunities." Academy of Management Perspectives 20, no. 1: 104-19.

Baron, Robert A., and Michael D. Ensley. 2006. “Opportunity Recognition as the Detection of Meaningful Patterns: Evidence from Comparisons of Novice and Experienced Entrepreneurs." Management Science 52, no. 9: 1331-44.

Baumol, William J. 1990. “Entrepreneurship: Productive, Unproductive, and Destructive. Journal of Political Economy 98, no. 1: 893-921.

Becker, Gary S. 1965. "A Theory of the Allocation of Time." Economic Journal 75, no. 299: 493-517.

-_ 1981. A Treatise on the Family. Cambridge, Mass.: Harvard University Press.

—. 2007. Economic Theory. New Brunswick, N.J.: Transaction Publishers.

Boettke, Peter J., and Christopher J. Coyne. 2009. Context Matters: Institutions and Entrepreneurship. Hanover, Mass.: Now Publishers Inc.

Buchanan, James M., and Vikto J. Vanberg. 1991. "The Market as a Creative Process." Economics and Philosophy 7, no. 2: 167-86.

Cantillon, Richard. 1755. Essai sur la nature du commerce en général. London: Macmillan. 
Chandler, Gaylen N., Dawn R. DeTienne, and Douglas W. Lyon. 2003. "Outcome Implications of Opportunity Creation / Discovery Processes." Paper presented at Babson Kauffman Entrepreneurship Research Conference, Babson College, Wellesley, Mass., 2003. https:// ssrn.com/abstract=1783698.

Chetty, Sylvie, Masoud Karami, and Oscar Martín Martín. 2018. “Opportunity Discovery and Creation as a Duality: Evidence from Small Firms' Foreign Market Entries." Journal of International Marketing 26, no. 3: 70-93.

Davidsson, Per. 2015. "Entrepreneurial Opportunities and the Entrepreneurship Nexus: A Re-conceptualization." Journal of Business Venturing 30, no. 5: 674-95.

Dempster, Gregory M. 1999. "Austrians and Post Keynesians: The Questions of Ignorance and Uncertainty." Quarterly Journal of Austrian Economics 2, no. 4: 73-81.

— 2015. "The Austrian Theory of Finance: Is It a Unique Contribution to the Field?" Pp. 563-75 in Oxford Handbook on Austrian Economics, ed. Peter J. Boettke and Christopher J. Coyne. New York: Oxford University Press: 563-75.

Dempster, Gregory, and Justin Isaacs. 2017. "Entrepreneurship, Corruption, and Economic Freedom." Journal of Entrepreneurship and Public Policy 6 , no. 2: 181-92.

Eckhardt, Jonathan T., and Scott A. Shane. 2003. "Opportunities and Entrepreneurship." Journal of Management 29: 333-49.

Edelman, Linda, and Helena Yli-Renko. 2010. “The Impact of Environment and Entrepreneurial Perceptions on Venture-Creation Efforts: Bridging the Discovery and Creation Views of Entrepreneurship." Entrepreneurship Theory and Practice 34, no. 5: 833-56.

Foss, Kirsten, and Nicolai J. Foss. 2008. “Understanding Opportunity Discovery and Sustainable Advantage: The Role of Transaction Costs and Property Rights. Strategic Entrepreneurship Journal 2, no. 3: 191-207.

Foss, Nicolai J., and Peter G. Klein. 2012. Organizing Entrepreneurial Judgment: A New Approach to the Firm. Cambridge: Cambridge University Press.

— . 2015. "Introduction to a Forum on the Judgment-Based Approach to Entrepreneurship: Accomplishments, Challenges, New Directions." Journal of Institutional Economics 11, no. 3: 585-99. 
Foss, Nicolai J., Peter G. Klein, and Christian Bjørnskov. 2019. “The Context of Entrepreneurial Judgment: Organizations, Markets, and Institutions." Journal of Management Studies 56, no. 6: 1197-1213.

Garud, Raghu, and Antonio Paco Giuliani. 2013. "A Narrative Perspective on Entrepreneurial Opportunities." Academy of Management Review 38, no. 1: $157-60$.

Godley, Andrew C., and Mark C. Casson. 2015. “'Doctor, Doctor...' Entrepreneurial Diagnosis and Market Making." Journal of Institutional Economics 11, no. 3: 601-21.

González, Mónica Félix, Bryan W. Husted, and Dennis J. Aigner. 2017. Opportunity Discovery and Creation in Social Entrepreneurship: An Exploratory Study in Mexico. Journal of Business Research 81, no. 12: 212-20.

Gorman, W. M. 1959. "Separable Utility and Aggregation." Econometrica 27, no. 3: 469-81.

_ . 1980. "A Possible Procedure for Analysing Quality Differentials in the Egg Market." Review of Economic Studies 47, no. 5: 843-56.

Goss, David, and Eugene Sadler-Smith. 2018. “Opportunity Creation: Entrepreneurial Agency, Interaction, and Affect." Strategic Entrepreneurship Journal 12, no. 2: 219-36.

Hallberg, Niklas L. 2015. "Uncertainty, Judgment, and the Theory of the Firm. Journal of Institutional Economics 11, no. 3: 623-50.

Harper, David A. 1996. Entrepreneurship and the Market Process: An Enquiry into the Growth of Knowledge. London: Routledge.

Hayek, Friedrich A. 1945. "The Use of Knowledge in Society." American Economic Review 35, no. 4: 519-30.

- 1948. Individualism and Economic Order. Chicago: University of Chicago Press.

- 1978. New Studies in Philosophy, Politics, Economics and the History of Ideas. Chicago: University of Chicago Press.

Hébert, Robert F., and Albert N. Link. 1982. The Entrepreneur: Mainstream Views and Radical Critiques. New York: Praeger. 
Hsieh, Chihmao, Jack A. Nickerson, and Todd R. Zenger. 2007. “Opportunity Discovery, Problem Solving and a Theory of the Entrepreneurial Firm." Journal of Management Studies 44, no. 7: 1255-77.

Hirschman, Albert O. 1958. The Strategy of Economic Development. New Haven, Conn.: Yale University Press.

Hitt, Michael A., R. Duane Ireland, and Robert E. Hoskisson. 2013. Strategic Management: Competitiveness and Globalization. 10th ed. Mason, Oh.: South-Western, Cengage Learning.

Knight, Frank H. 1921. Risk, Uncertainty, and Profit. Boston: Houghton Mifflin.

Kirzner, Israel M. 1973. Competition and Entrepreneurship. Chicago: University of Chicago Press.

- 1979. Perception, Opportunity and Profit: Studies in the Theory of Entrepreneurship. Chicago: University of Chicago Press.

- 1985. Discovery and the Capitalist Process. Chicago: University of Chicago Press.

—. 1997. "Entrepreneurial Discovery and the Competitive Market Process: An Austrian Approach." Journal of Economic Literature 35: 60-85.

Klein, Peter G. 2008. “Opportunity Discovery, Entrepreneurial Action, and Economic Organization." Strategic Entrepreneurial Journal 2: 175-90.

Koellinger, Philipp. 2008. “Why Are Some Entrepreneurs More Innovative Than Others?" Small Business Economics 31: 21-37.

Koppl, Roger. 2008. “Computable Entrepreneurship." Entrepreneurship Theory and Practice 32, no. 5: 919-26.

Koppl, Roger, Stuart Kauffman, Teppo Felin, and Giuseppe Longo. 2015. "Economics for a Creative World." Journal of Institutional Economics 11, no. 1: 1-31.

Lancaster, Kelvin J. 1966. "A New Approach to Consumer Theory." Journal of Political Economy 74, no. 2: 132-57.

—. 1971. Consumer Demand: A New Approach. New York: Columbia University Press. 
Lewin, Peter. 2015. “Entrepreneurial Opportunity as the Potential to Create Value." Review of Austrian Economics 28, no. 1: 1-15.

Luksha, Pavel. 2008. "Niche Construction: The Process of Opportunity Creation in the Environment." Strategic Entrepreneurship Journal 2, no. 4: 269-83.

Mainela, Tujia, and Vesa Puhakka. 2009. “Organising New Business in a Turbulent Context: Opportunity Discovery and Effectuation for IJV Development in Transition Markets." Journal of International Entrepreneurship 7: 111.

Martin, Lee, and Nick Wilson. 2016. "Opportunity, Discovery and Creativity: A Critical Realist Perspective." International Small Business Journal 34, no. 3: 261-75.

Mill, John Stuart. 1848 [1871]. Principles of Political Economy: With Some of Their Applications to Social Philosophy. People's ed. London: Longmans, Green, Reader, and Dyer.

Mitchell, J. Robert, Ronald K. Mitchell, Benjamin T. Mitchell, and Sharon Alvarez. 2012. "Opportunity Creation, Underlying Conditions, and Economic Exchange." Pp. 89-123 in Entrepreneurial Action, ed. Andrew C. Corbett and Jerome A, Katz. Vol. 14 of Advances in Entrepreneurship, Firm Emergence and Growth. Bingley, U.K.: Emerald Group Publishing Limited.

Mises, Ludwig von. [1949] 1996. Human Action: A Treatise on Economics. 4th rev. ed. New York: Foundation for Economic Education.

McCaffrey, Matthew. 2014. “On the Theory of Entrepreneurial Incentives and Alertness." Entrepreneurship Theory and Practice 38, no. 4: 891-911.

- 2015. "Economic Policy and Entrepreneurship: Alertness or Judgment?" Pp. 183-200 in The Next Generation of Austrian Economists: Essays in Honor of Joseph T. Salerno, ed. Per Bylund and David Howden. Auburn, Ala.: Mises Institute.

McMullen, Jeffery S. 2015. “Entrepreneurial Judgment as Empathic Accuracy: A Sequential Decision-Making Approach to Entrepreneurial Action." Journal of Institutional Economics 11, no. 3: 651-81.

McMullen, Jeffery S., and Dean A. Shepherd. 2006. "Entrepreneurial Action and the Role of Uncertainty in the Theory of the Entrepreneur." Academy of Management Review 31, no. 1: 132-52. 
Ojala, Arto. 2016. “Business Models and Opportunity Creation: How IT Entrepreneurs Create and Develop Business Models under Uncertainty." Information Systems Journal 26, no. 5: 451-76.

Ozgen, Eren, and Robert A. Baron. 2007. "Social Sources of Information in Opportunity Recognition: Effects of Mentors, Industry Networks, and Professional Forums." Journal of Business Venturing 22, no. 2: 174-92.

Parmar, Bidhan L., R. Edward Freeman, Jeffrey S. Harrison, Andrew C. Wicks, Lauren Purnell, and Simone de Colle. 2010. "Stakeholder Theory: The State of the Art." Academy of Management Annals 4, no. 1: 403-45.

Puhakka, Vesa Johannes. 2010. "Versatile and Flexible Use of Intellectual Capital in Entrepreneurial Opportunity Discovery." Journal of Management Research 2, no. 1: 1-26.

Ramoglou, Stratos, and Eric W. K. Tsang. 2016. A Realist Perspective of Entrepreneurship: Opportunities as Propensities." Academy of Management Review 41, no. 3: 410-34.

— . 2017. "In Defense of Common Sense in Entrepreneurship Theory: Beyond Philosophical Extremities and Linguistic Abuses." Academy of Management Review 42, no. 4: 736-44.

Sarasvathy, Saras D. 2001. "Causation and Effectuation: Toward a Theoretical Shift from Economic Inevitability to Entrepreneurial Contingency." Academy of Management Review 26, no. 2: 243-63.

Sarasvathy, Saras D., and Nicholas Dew. 2013. "Without Judgment: An Empirically-Based Entrepreneurial Theory of the Firm." Review of Austrian Economics 26, no. 3: 277-96.

Sarasvathy, Saras D., Nicholas Dew, S. Ramakrishna Velamuri, and Sankaran Venkataraman. 2003. "Three Views of Entrepreneurial Opportunity." Pp. 141-60 in Handbook of Entrepreneurship Research: An Interdisciplinary Survey and Introduction, ed. Zoltan J. Acs and David B. Audretsch. Dordrecht, Netherlands: Kluwer Academic Publishers.

Sarasvathy, Saras D., and Sankaran Venkataraman. 2011. "Entrepreneurship as Method: Open Questions for an Entrepreneurial Future." Entrepreneurship Theory and Practice 35, no. 1: 113-35.

Say, Jean-Baptiste. 1821 [1880]. A Treatise on Political Economy, or the Production, Distribution, and Consumption of Wealth. Philadelphia: Claxton, Remsen, and Haffelfinger. 
Schumpeter, Joseph A. 1934. The Theory of Economic Development: An Inquiry into Profits, Capital, Credit, Interest, and the Business Cycle. Cambridge, Mass.: Harvard University Press.

Shane, Scott. 2000. "Prior Knowledge and the Discovery of Entrepreneurial Opportunities." Organization Science 11, no. 4: 448-69.

- 2003. A General Theory of Entrepreneurship: The Individual-Opportunity Nexus. Cheltenham, U.K.: Edward Elgar.

Shane, Scott, and Sankaran Venkataraman. 2000. "The Promise of Entrepreneurship as a Field of Research." Academy of Management Review 25, no. 1: 217-26.

Shepherd, Dean. 2015. "Party on! A Call for Entrepreneurship Research That Is More Interactive, Activity Based, Cognitively Hot, Compassionate, and Prosocial." Journal of Business Venturing 30, no. 4: 489-507.

Shu, Rui, Shenggang Ren, and Yi Zheng. 2018. "Building Networks into Discovery: The Link between Entrepreneur Network Capability and Entrepreneurial Opportunity Discovery." Journal of Business Research 85, no. 4: 197-208.

Smith, Adam. [1776] 1993. An Inquiry into the Nature and Causes of the Wealth of Nations. Ed. Kathryn Sutherland. Oxford: Oxford University Press.

Sobel, Russell S. 2008. "Testing Baumol: Institutional Quality and the Productivity of Entrepreneurship." Journal of Business Venturing 23, no. 6: 641-55.

Sobel, Russell S., J. R. Clark, and Dwight R. Lee. 2007. “Freedom, Barriers to Entry, Entrepreneurship, and Economic Progress. Review of Austrian Economics 20, no. 4: 221-36.

Venkataraman, Sankaran. 1997. "The Distinctive Domain of Entrepreneurship Research." Advances in Entrepreneurship, Firm Emergence, and Growth 3, no. 1: 119-38.

Venkataraman, Sankaran, Saras D. Sarasvathy, Nicholas Dew, and William R. Forster. 2012. "Reflections on the 2010 AMR Decade Award: Whither the Promise? Moving forward with Entrepreneurship as a Science of the Artificial." Academy of Management Review 37, no. 1: 21-33.

Wood, Matthew S., and William McKinley. 2010. "The Production of Entrepreneurial Opportunity: A Constructivist Perspective." Strategic Entrepreneurship Journal 4, no. 1: 66-84. 
— . 2020. "The Entrepreneurial Opportunity Construct: Dislodge or Leverage?" Academy of Management Perspectives 34, no. 3. https:// journals.aom.org/doi/epdf/10.5465/amp.2017.0162.

Zahra, Shaker A. 2008. "The Virtuous Cycle of Discovery and Creation of Entrepreneurial Opportunities." Strategic Entrepreneurship Journal 2, no. 3: 243-57. 